\title{
The synthesis of new barbiturate esters derivatives as intravenous anesthetics: a new dimension of anesthesia route part-IV
}

\begin{abstract}
Conventional 1-methyl-2-oxybarbiturates and 1-methyl-2-thiobarbiturates are employed as anesthetics and tend to accumulate in the body due to their slow rate of metabolism. As a result, the use of these compounds is restricted to either being an induction agent for anesthesia, subsequently maintained by volatile anesthetics, or for short surgical procedures only. To overcome these limitations of barbiturates as general anesthetics, and to avoid the use of volatile agents, structural modifications of barbiturates molecules as intravenous anesthetics were attempted. It was conceived that, by incorporating metabolically labile ester functions in one or both of the side chain of the barbiturates ring system, this could be achieved. Since this procedure could diminish the likelihood of barbiturates to be accumulated in the body, it would make it possible to get safer barbiturate intravenous anesthetics. This classification arose from the observation that while the biological properties of some drugs are extremely sensitive to minor changes in the stereo-chemical feature, electron distribution, and substituent, there are many other drugs which exhibit similar patterns of biological behavior, despite a wide diversity in their chemical configurations This has appeared to be the case with the barbiturate esters as discussed.
\end{abstract}

Keywords: barbiturates, intravenous anesthetics, metabolically labile ester
Volume 4 Issue 3 - 2019

\author{
Md Ehsanul Huq,Amit Sarker \\ Department of Pharmacy, Primeasia University, Bangladesh
}

Correspondence: Dr. Md. Ehsanul Huq, Professor, Department of Pharmacy, Primeasia University, Banani, Dhaka, Bangladesh, Tel 88(02)01768727080, 88(02)91।4964,

Email prof.ehsanulhuq@primeasia.edu.bd

Received: April 18, 2019 | Published: June 12, 2019

\section{Introduction}

The synthesis and preliminary biological investigations of twenty seven (27) barbiturates containing ester function, in one of the side chains have been reported in this communication. A few related barbiturates, needed for the synthesis of esters, have also been reported. The currently accepted explanation of the short action of barbiturate anesthetics is the distribution of drugs into the tissues and fats within the body compartments and to some degree of metabolism. It is, however, known that barbiturate anesthetics are not rapidly metabolized in the body but are instead accumulated in the tissues and fats making elimination a slow process thus causing hangover among patients. The investigator, therefore, assumed that it could be possible to provide anesthetics barbiturate through molecular modifications which would undergo rapid metabolism and thereby offer critical clinical advantages. It was thought that there was a need for a potent and fast-acting agent which, because of the rapid metabolic breakdown and elimination from the body, allows the restoration of mental faculties within a short period after surgery and without a persistent hangover or a headache. The first barbiturate used as an intravenous anesthetic was hexobarbitone which was quickly replaced by short-acting thiopentone. However, its use remained only to simple surgical procedures, lasting for a very brief period, because of its very short duration of action. Since Thiopentone tends to accumulate in the body, its use was limited to that of an induction agent only, and substantial precautions had to be taken by the anesthetists given its low therapeutic index. Considering these complex properties of barbiturates molecules, it was assumed that molecular modifications could alter the properties of barbiturates by improving their lipid solubility. This could be achieved either by introducing alkyl or aryl groups in side chain or ring nitrogen atoms or by replacing one of the ring oxygen with sulfur or selenium. Mauttner ${ }^{1}$ reported that by increasing the side length to up to eight carbon atoms, both potency and lipid solubility rise. Beyond eight carbon atoms, results either produce convulsion or inactive compounds. The probable explanation is that the lipid solubility of the drug molecule reached such a level that it accumulated in body fats and could not reach its receptors. The presence of ester function in many drugs like cholinergic, anti-cholinergic and local anesthetics are responsible for their susceptibility to the action of plasma esterase, and these drugs are rapidly metabolized and quickly eliminated from the body. Further, the introduction of ester functions in the decamethylene chain of the neuromuscular blocking agent decamethonium has been exploited to overcome the prolonged action of the compound. The resulting drug Suxamethonium is widely used in surgery. Given the above discussion, a pragmatic plan was undertaken, and 6 and 31 barbiturate ester derivatives were synthesized, analyzed and their biological investigation was conducted on mice, rats and in some cases rabbits and reported in two instalments. ${ }^{2,3}$ Following is a list of eighteen new barbiturate esters derivatives, along with their biological results (Table I-VII).

Table I

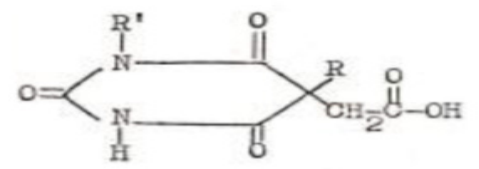

$$
\begin{aligned}
& \text { I06a. } R=\text { s-Bu; } R^{\prime}=H \\
& \text { I06b. } R=P h ; R^{\prime}=H \\
& \text { I06c. } R=s-B u ; R^{\prime}=\mathrm{CH}_{3} \\
& \text { I06d. } R=\text { Pentyl; } R^{\prime}=\mathrm{CH}_{3} \\
& \text { I06e. } R=\text { Hexyl; } R^{\prime}=\mathrm{CH}_{3}
\end{aligned}
$$


Table 2

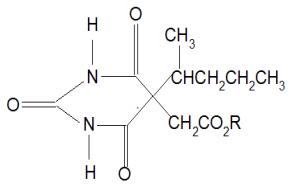

\begin{tabular}{|c|c|c|c|c|c|c|c|c|}
\hline $\begin{array}{l}\text { Compound } \\
\text { no }\end{array}$ & $\mathbf{R}$ & $\pi$ & Ro & $\sigma \mathbf{x}$ & $\begin{array}{l}\text { Dose } \\
\mathrm{mg} / \mathrm{kg}\end{array}$ & $\%$ Anesthesia & $\begin{array}{l}\text { Duration in } \\
\text { mins }\end{array}$ & $\%$ depth \\
\hline \multirow[t]{3}{*}{107} & $-\left(\mathrm{CH}_{2}\right)_{3} \mathrm{CH}_{3}$ & 2 & -0.39 & -0.13 & 75 & - & - & \\
\hline & & & & & 100 & 100 & $8.2+0.57$ & \\
\hline & & & & & 150 & 100 & $17.93+2.12$ & $40(60)$ \\
\hline \multirow[t]{2}{*}{108} & $-\mathrm{CH}\left(\mathrm{CH}_{3}\right)_{2}$ & 1.30 & -0.47 & -0.19 & 100 & - & - & \\
\hline & & & & & 150 & 100 & $42.65+5.44$ & \\
\hline \multirow[t]{4}{*}{109} & $-\mathrm{CH}_{2} \mathrm{CH}\left(\mathrm{CH}_{3}\right)_{2}$ & 1.80 & -0.93 & -0.13 & 50 & - & - & \\
\hline & & & & & 75 & 60 & $4.75+1.25$ & \\
\hline & & & & & 100 & 100 & $6.8+0.8$ & \\
\hline & & & & & 150 & 100 & $6.22+1.24$ & $10(30)$ \\
\hline 110 & $-\mathrm{CH}_{2} \mathrm{C}_{6} \mathrm{H}_{5}$ & 2.27 & 0.22 & - & 100 & - & - & \\
\hline 111 & $-\left(\mathrm{CH}_{2}\right)_{2} \mathrm{CH}_{3}$ & 1.5 & -0.36 & -0.12 & 100 & 70 & $7.93+1.08$ & \\
\hline \multirow[t]{2}{*}{112} & $-\left(\mathrm{CH}_{2}\right)_{4} \mathrm{CH}_{3}$ & 2.5 & -0.4 & $(-0.15)$ & 50 & - & - & -20 \\
\hline & & & & & 100 & - & - & 100 \\
\hline
\end{tabular}

Table 3

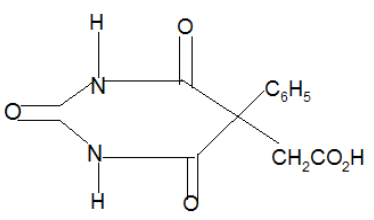

\begin{tabular}{|c|c|c|c|c|c|c|c|c|}
\hline $\begin{array}{l}\text { Compound } \\
\text { No }\end{array}$ & $\mathbf{R}$ & $\pi$ & Ro & $\sigma x$ & $\begin{array}{l}\text { Dose } \\
\mathrm{mg} / \mathrm{kg}\end{array}$ & $\%$ Anesthesia & $\begin{array}{l}\text { Duration } \\
\text { in mins }\end{array}$ & $\%$ depth \\
\hline 113 & $-\left(\mathrm{CH}_{2}\right)_{2} \mathrm{CH}_{3}$ & 1,50 & -0.36 & -0.12 & 200 & - & - & \\
\hline \multirow[t]{4}{*}{114} & $-\left(\mathrm{CH}_{2}\right)_{3} \mathrm{CH}_{3}$ & 2 & -0.39 & -0.13 & 50 & 70 & 7 & \\
\hline & & & & & 75 & 100 & 7 & \\
\hline & & & & & 100 & 100 & 12.4 & \\
\hline & & & & & 150 & 100 & 16.1 & 10 \\
\hline \multirow[t]{2}{*}{115} & $-\left(\mathrm{CH}_{2}\right)_{4} \mathrm{CH}_{3}$ & 2.5 & 0.4 & $(-0.15)$ & 75 & 40 & $4.0+1.21$ & \\
\hline & & & & & 100 & 100 & $6.40+0.62$ & \\
\hline 116 & $-\mathrm{CH}\left(\mathrm{CH}_{3}\right)_{2}$ & 1.30 & -0.47 & -0.19 & - & - & & \\
\hline 117 & $-\mathrm{CH} 2 \mathrm{CH}\left(\mathrm{CH}_{3}\right)_{2}$ & 1.80 & -0.93 & -0.13 & - & - & & \\
\hline
\end{tabular}

Citation: Huq ME, Sarker A.The synthesis of new barbiturate esters derivatives as intravenous anesthetics: a new dimension of anesthesia route part-IV. Int J Mol Biol Open Access. 2019;4(3):96-104. DOI: 10.15406/ijmboa.2019.04.00 I04 


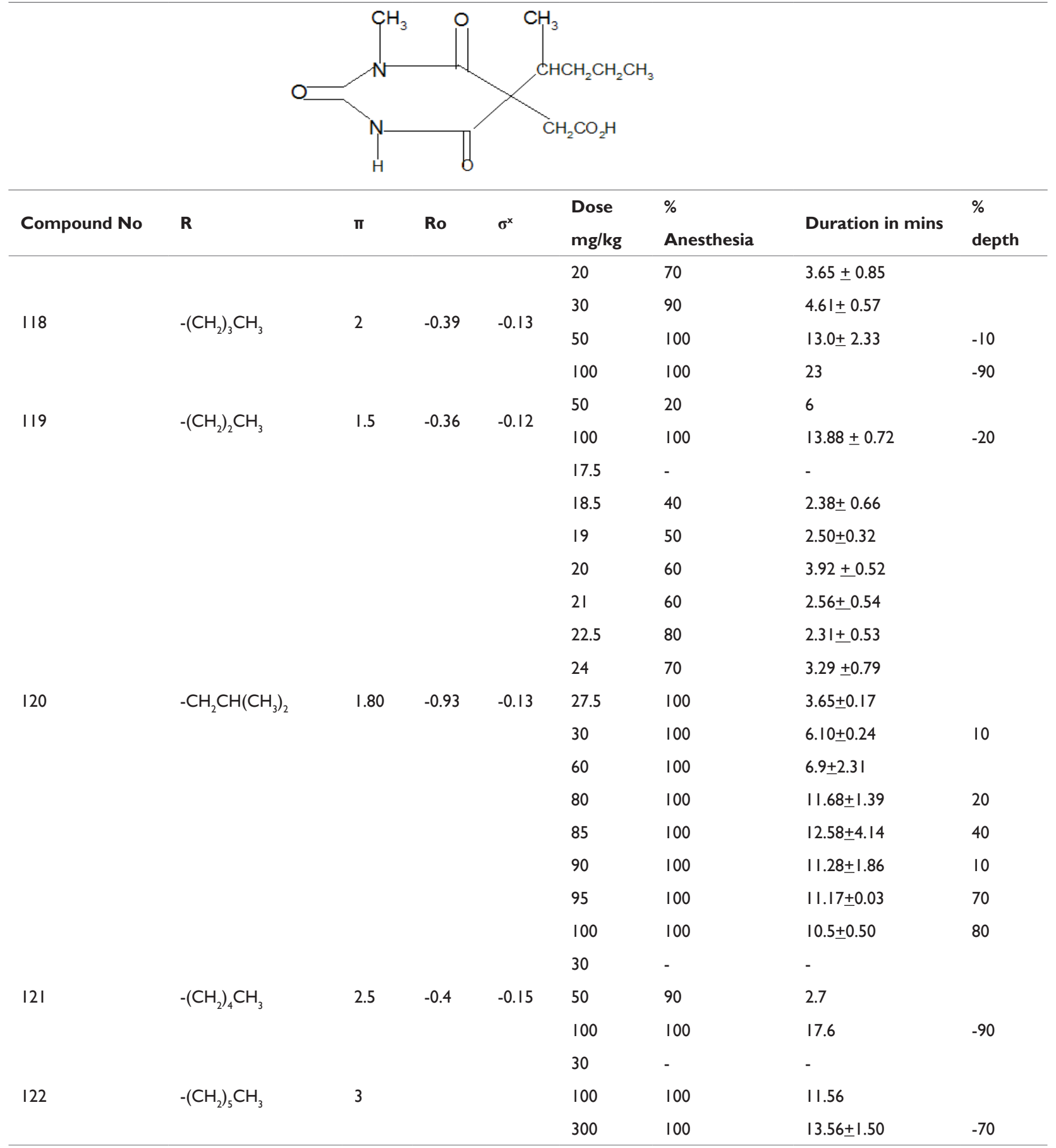

\section{Experimental}

Melting points: Melting points were recorded either in Koffler Heizbench type 184321 or Reichert's Microscopic Melting point Apparatus.

Thin layer chromatography: Plates: Silica Gel Plates were used except where specifically mentioned otherwise. Both extemporaneously prepared plates (MN-Duren, MN-Kieselgel $\mathrm{G}-\mathrm{HR}$ ) and MN-Duren polygram- Sil G/UV ${ }_{254}$ plates were found to be satisfactory.

Development solvent: A mixture of Chloroform and Acetone in the ratio of $1: 1$

Spray reagent: Plates were sprayed with a saturated aqueous solution of Silver acetate, dried, and sprayed with a $10 \%$ diphenyl carbazone aqueous solution in which required quantity of ethanol had been added to assist dissolution of the solute. Barbiturates appeared as lilac spot on the chromatograms. 
Biological evaluation: All Barbiturate Esters reported in this article were tested on male mice (CELP), usually a group 10 (18-22g). Drugs were administered intravenously as sodium salts in physiological saline, unless otherwise stated. Letters $\mathrm{m}, \mathrm{w}$ and $\mathrm{c}$ in tables stand for $5 \%$ mulgofen, carbon dioxide free distilled water and convulsion respectively. Percentage death figure in tabled refers acute toxicity, whilst delay toxicity (over 24 hours) has been shown in brackets. The numerical numbers refers to as experimental protocol numbers.

\section{Synthesis}

Synthesis of 5-(1-Methylbutyl)-5-Carboxymethyl barbituric acid(106a): 5-(1-Methylbutyl)-5-Allylbarbituric acid (50g) was dissolved in a minimum quantity (volume) of $10 \%$ aqueous solution of sodium carbonate and any insoluble materials were filtered off. A saturated solution of potassium permanganate was then slowly added until the reaction was complete ( tested by putting a drop of the solution on to a piece of filter paper and observed until the edge of the violet color of the edge of the drop persisted 3-5 minutes). The reaction mixture was then acidified with Conc. Hydrochloric acid and treated with solid sodium metabisulfite to get clear and colorless solution after filtration. This solution was extracted with diethyl ether, washed with water, dried over anhydrous sodium sulfate and the solvent removed. The oily mass on crystallization from boiling water afforded needles of compound (106a; $17 \mathrm{~g}, 32 \%)$, mp. $236-38)^{\circ} \mathrm{C}$. Found: C,51.25 and $\mathrm{H}, 6.30 \% . \mathrm{C}_{11} \mathrm{H}_{16} \mathrm{~N}_{2} \mathrm{O}_{5}$ requires: C,51.60 and $\mathrm{H}, 6.20 \%$.

Synthesis of Butyl 5-(1-methylbutyl) barbituric acid-5-methylene carboxylate(107): The barbiturate carboxylic acid $(2 \mathrm{~g})$ was refluxed with stirring in butanol $(10 \mathrm{ml})$ in the presence of a few drops conc. Sulfuric acid for $6 \mathrm{~h}$. The solvent was removed and the residue was taken in ether, washed with water, dried over anhydrous sodium sulfate and concentrated to small volume. This was chromatographed over basic alumina column and the $2 \%$ ethanol in ether elueate was crystallized from ether-petroleum ether $40-60^{\circ} \mathrm{C}$ to give needles of compound (107); (1.40g; 58\%), mp. $78-80^{\circ} \mathrm{C}$. Found: C , 57.95; $\mathrm{H}, 7.70 ; \mathrm{N}, 9.90 \% \quad \mathrm{C}_{15} \mathrm{H}_{24} \mathrm{~N}_{2} \mathrm{O}_{5}$ requires : $\mathrm{C}, 57.70 ; \mathrm{H}, 7.70$ and $\mathrm{N}, 9.00 \%$.

Synthesis of Isopropyl 5-(1-methylbutyl)barbituric acid-5methylene carboxylate(108): The barbiturate carboxylic acid 106a $(2 \mathrm{~g})$ was refluxed in isopropyl alcohol $(6 \mathrm{ml})$ in the presence of concentrated sulphuric acid, as for 107 . The $2 \%$ ethanol in the eluate from basic alumina gave the ester $(1.3 \mathrm{~g}, 55 \%)$ as an oil.

Synthesis of Isobutyl 5-(1-methylbutyl) barbituric acid-5methylene carboxylate(109): The barbiturate carboxylic acid (106a) $(2 \mathrm{~g})$ was refluxed in isobutyl alcohol $(6 \mathrm{ml})$ in the presence of a few drops of sulfuric acid for $6 \mathrm{~h}$. This reaction mixture was worked out as in (107) to produce white crystals of the compound (109), (1.3g; 54\%), mp. $124-26^{\circ}$ C. Found: C,58.15; H,7.75 and N,8.70\%. $\mathrm{C}_{15} \mathrm{H}_{24} \mathrm{~N}_{2} 0_{5}$ requires: $\mathrm{C}, 57.70 ; \mathrm{H}, 7.70$ and $\mathrm{N}, 9.90 \%$.

Synthesis of Benzyl 5-(1-Methylbutyl) barbituric acid-5methylene carboxylate (110): The barbiturate carboxylic acid (106a) $(2 \mathrm{~g})$ was refluxed in benzyl alcohol $(6 \mathrm{ml})$ in which a few drops of sulfuric acid for $6 \mathrm{~h}$. The solvent was removed and the product was taken in required amount of $(\mathrm{N})$ hydrochloric acid and extracted with ether, washed with water, dried over anhydrous sodium sulfate and the solvent was removed. The product was chromatographed over basic alumina and crystallized from ether-petroleum ether $\left(40-60^{\circ} \mathrm{C}\right)$ to provide fine crystals $(1.2 \mathrm{~g} ; 44 \%), \mathrm{mp} .140-42^{\circ} \mathrm{C}$. Found: $\mathrm{C}, 62.85$;
$\mathrm{H}, 6.60$ and $\mathrm{N}, 8.30 \% . \mathrm{C}_{18} \mathrm{H}_{22} \mathrm{~N}_{2} \mathrm{O}_{5}$ requires: $\mathrm{C}, 62.40, \mathrm{H}, 6.40$ and $\mathrm{N}, 8.0 \%$.

Synthesis of Propyl 5-(1-methylbutyl) barbituric acid-5methylene carboxylate (111): The barbiturate carboxylic acid (106a) $(2 \mathrm{~g})$ was refluxed in propyl alcohol $(6 \mathrm{ml})$ for $6 \mathrm{~h}$. The reaction mixture was worked out as for compound (110) which afforded the compound (111) as colorless crystals $(1.32 \mathrm{~g} ; 57 \%)$, mp. $138-40^{\circ} \mathrm{C}$. Found: $\mathrm{C}, 56.80 ; \mathrm{H}, 7.50$ and $\mathrm{N}, 9.60 \% . \mathrm{C}_{14} \mathrm{H}_{22} \mathrm{~N}_{2} \mathrm{O}_{5}$ requires: $\mathrm{C}, 56.40 ; \mathrm{H}, 7.40$ and $\mathrm{N}, 9.4 \%$.

Synthesis of Pentyl 5-(1-methylbutyl) carboxylic acid-5-methylene carboxylate (112): The experimental and working out procedures are same as applied for the synthesis of compound (111) where amyl alcohol was used.

Synthesis of 5-phenyl -5-carboxymethyl barbituric acid (106b): 5-Phenyl -5-allyl barbiturate $(27 \mathrm{~g})$ was subjected to oxidation as described under the synthesis of compound (106a). The reaction provided an oil which was dissolved in acetone and the slowly added chloroform to induce crystallization. The colorless crystals $(10 \mathrm{~g}$; $35 \%$ ), gave mp. $260-6^{\circ} \mathrm{C} ; \mathrm{R}_{\mathrm{ff}} 0.02$

Synthesis of Propyl 5-phenylbarbituric acid-5-methylene carboxylate (113): The barbiturate carboxylic acid 106b (2g) was refluxed in propyl alcohol $(6 \mathrm{ml})$ with a few drops of concentrated sulphuric acid, as described for 107 . The $2 \%$ ethanol in ether eluate from basic alumina gave the barbiturate ester as an oil $(1.36 \mathrm{~g}, 59 \%)$, $\mathrm{R}_{\mathrm{F}} 0.61$.

Synthesis of Butyl 5-phenylbarbituric acid-5-methylene carboxylate (114): This compound was processed and worked out exactly as of (107) where $(2 \mathrm{~g})$ of $(106 \mathrm{~b})$ produced needles of compound (114) (1.40g; 55\%), mp. $160-62^{\circ} \mathrm{C}$. Found: C, 60.90; H,5.70 and $\mathrm{N}, 8.50 \% . \mathrm{C}_{16} \mathrm{H}_{18} \mathrm{~N}_{2} \mathrm{O}_{5}$ requires: $\mathrm{C}, 60.40 ; \mathrm{H}, 5.65$ and $\mathrm{N}, 8.80 \%$.

Synthesis of Phenyl 5-phenylbarbituric acid-5-methylene carboxylate (115): The barbiturate carboxylic acid 106b (2g) was refluxed in amyl alcohol $(6 \mathrm{ml})$ in the presence of a few drops of sulphuric acid, as for 110 . The resulting product was chromatographed on basic alumina and the $2 \%$ ethanol in ether eluate on crystallisation from ether-petroelum ether $\left(40-60^{\circ} \mathrm{C}\right)$ gave the barbiturate ester $(1.4 \mathrm{~g}$, $55 \%)$, m.p. $158-60^{\circ} \mathrm{C}$.

Synthesis of Isopropyl 5-phenylbarbituric acid-5-methylene carboxylate (116): The barbiturate carboxylic acid 106b (2g) was refluxed in isopropyl alcohol $(6 \mathrm{ml})$ in the presence of concentrated sulphuric acid, as for 107 . The $2 \%$ ethanol in ether eluate from basic alumina on crystallisation from ether-petroleum ether $\left(40-60^{\circ} \mathrm{C}\right)$ gave clolourless crystals of the barbiturate ester $(1.45 \mathrm{~g}, 63 \%)$, m.p. 250 $52^{\circ} \mathrm{C}$.

Synthesis of Isobutyl 5-phenylbarbituric acid -5-methylene carboxylate (117): The reaction was carried out using (2g) of compound (106b) and isobutyl alcohol $(6 \mathrm{ml})$ and worked as in compound (114) when the compound (117) was obtained as needles (1.48g, 61\%), mp. $208-210^{\circ} \mathrm{C}$. Found: C,60.40; H,5.75. $\mathrm{C}_{16} \mathrm{H}_{18} \mathrm{~N}_{2} \mathrm{O}_{5}$ requires: $\mathrm{C}, 60.40$ and $\mathrm{H}, 5.65 \%$.

Synthesis of 1-Methyl-5-(1'-methylbutyl)-5-carboxymethyl barbituric acid (106c): This compound can be prepared by two methods:

Method-1: This method is identical as described under (106a), 
the barbiturate carboxylic being obtained from 1-methyl-5-(1'methylbutyl)-5-allylbarbituric acid (19g) by oxidation with potassium permanganate. Re-crystallization of the resulting product either from boiling water or from ether-petroleum ether (40-60\%) mixture gave compound $(106 \mathrm{c})(9 \mathrm{~g} ; 45 \%), \mathrm{mp} .182-83^{\circ} \mathrm{C}$. Found: C,53.10; H,6.70 and $\mathrm{N}, 10.50 \% . \mathrm{C}_{12} \mathrm{H}_{18} \mathrm{~N}_{2} \mathrm{O}_{5}$ requires: $\mathrm{C}, 53.30 ; \mathrm{H}, 6.70$ and $\mathrm{N}, 10.40 \%$.

Method-II: Ethyl 1-methyl-5-(1"-methylbutyl) barbituric acid carboxylate $(8.9 \mathrm{~g})$ was hydrolysed with $20 \%$ hydrochloric acid and the product $(7.10 \mathrm{~g})$ was crystalised with boiling water afforded pure compound, mp. $183-85^{\circ} \mathrm{C}$. Found: C,53.4; H,6.70 and N,10.55\%.

Synthesis of Butyl 1-methyl -5-(1"-methylbutyl) barbituric acid -5-methylene carboxylate (118): The (2g) barbiturate carboxylic acid (106c) after reaction and working out as for compound (107) gave the required ester (118) $(1.53 \mathrm{~g} ; 64 \%), \mathrm{mp} .102-103^{\circ} \mathrm{C}$. The compounds (119) and (120) were prepared in the same way as compound (107) and carried out their biological screening.

Synthesis of 1-Methyl -5-(1'-methylbutyl) barbituric acid: Methyl urea (33g) was dissolved in sodium methoxide solution (94g) to which diethyl 1-methylbutyl malonate (94g) added and refluxed for 2.5 hours. The solvent was distilled off and the residue was taken in water, washed with ether to remove any un-reacted malonate. The aqueous solution was acidified with dilute hydrochloric acid and extracted with ether. The ethereal solution was washed with water, dried over anhydrous sodium sulfate, solvent removed and chromatographed on neutral alumina. The oil thus obtained was crystallized from ether pet-ether $(40-60 \%)$ to give needles of the compound $(137.80 \mathrm{~g} ; 86 \%)$, mp. 98-100. Found: C,556.20; $\mathrm{H}, 7.50$ and $\mathrm{N}, 12.80 \% . \mathrm{C}_{10} \mathrm{H}_{16} \mathrm{~N}_{2} \mathrm{O}_{5}$ requires: $\mathrm{C}, 565.60 ; \mathrm{H}, 7.50$ and $\mathrm{N}, 13.20 \%$

Synthesis of Propyl 1-methyl-5-(1'-methylbutyl)barbituric acid-5methylene carboxylate (119): The barbiturate carboxylic cid 106c $(2 \mathrm{~g})$ was refluxed in propyl alcohol in the presence of a few drops of concentrated sulphuric acid, as for 107 . The $2 \%$ ethanol in ether eluate from basic alumina was crystallised from ether-petroleum ether (40$\left.60^{\circ} \mathrm{C}\right)$ to give the barbiturate ester $(1.73 \mathrm{~g}, 60 \%)$, m.p. $66-70^{\circ} \mathrm{C}$.

Synthesis of Isobutyl 1-methyl-5-(1'-methylbutyl)barbituric acid5-methylene carboxylate (120): The barbiturate carboxylic acid 106c $(2 \mathrm{~g})$ was refluxed in isobutyl alcohol in the presence of a few drops of concentrated sulphuric acid, as described for 107. The oil obtained from the $2 \%$ ethanol in ether eluate from basic alumina crystallised from ether-petroleum ether $\left(40-60^{\circ} \mathrm{C}\right)$ to give the barbiturate ester (1.70g, 71\%), m.p. $106-7^{\circ} \mathrm{C}, \mathrm{R}_{\mathrm{F}} 0.63$.

1-Methyl-5-(1'-methylbutyl)barbituric acid: Methyl urea (33g) was dissolved in sodium methoxide solution $(94 \mathrm{~g})$ to which diethyl 1-methylbutylmalonate $(94 \mathrm{~g})$ had been added before refluxing for $2^{1 / 2} \mathrm{~h}$. Solvent was distilled off and the residue was dissolved in water (extracted with ether to remove any unreacted malonate), acidified with dilute hydrochloric acid and extracted with ether. The extract was then washed with water, dried, $\left(\mathrm{Na}_{2} \mathrm{SO}_{4}\right)$ and chromatographed on neutral alumina. The oil obtained from ether eluate was crystallised from either ether or ether-petroleum ether $\left(40-60^{\circ} \mathrm{C}\right)$ to give needles of 1-methyl-5-(1'-methylbutyl)barbituric acid (137.8g, 86\%), m.p. 98$100^{\circ}$ (Found: $\mathrm{C}, 56.2 ; \mathrm{H}, 7.5 ; \mathrm{N}, 12.8 . \mathrm{C}_{10} \mathrm{H}_{16} \mathrm{~N}_{2} \mathrm{O}_{3}$ requires $\mathrm{C}, 56.6 ; \mathrm{H}$, $7.5 ; \mathrm{N}, 13.2 \%), \mathrm{R}_{\mathrm{F}} 0.41$.

Synthesis of Ethyl 1-methyl-5-(1'-methylbutyl) barbituric acid-5methylene carboxylate(120a): 1-Methyl-5-(1'-methylbutyl barbituric acid $(10 \mathrm{~g})$ was dissolved in minimal volume of absolute ethanol and added to sodium ethoxide $(1.15 \mathrm{~g})$. Ethylchloroacetate $(6.25 \mathrm{~g})$ and potassium iodide $(0.25 \mathrm{~g})$ were added to this mixture and refluxed for 48 hours. Sodium chloride crystals deposited was filtered off and the solvent was removed from the reactant when an oily mass was obtained. This after chromatography and crystallization gave the compound (120a), (11.52g; 82\%), mp. $72-73^{\circ} \mathrm{C}$. Found: C,56.50; $\mathrm{H}, 7.60$ and $\mathrm{N}, 9.20 \% . \mathrm{C}_{14} \mathrm{H}_{22} \mathrm{~N}_{2} \mathrm{O}_{5}$ requires: $\mathrm{C}, 56.40 ; \mathrm{H}, 7.40$ and $\mathrm{N}, 9.4 \%$.

1-Methyl-5-pentyl barbituric acid: Methyl urea (74g) was dissolved in sodium methoxide solution $(216 \mathrm{~g})$ to which diethyl pentyl malonate $(230 \mathrm{~g})$ was added and the mixture refluxed for 2.5 hours. After crystallization needles of the barbiturates was obtained $(187 \mathrm{~g})$, mp. $90-91^{\circ} \mathrm{C}$.

Synthesis of Pentyl 1-methyl-5-(1'-methylbutyl)barbituric acid-5methylene carboxylate (121): The barbiturate carboxylic acid 106c $(2 \mathrm{~g})$ was refluxed in amyl alcohol $(6 \mathrm{ml})$ in the presence of a few drops of concentrated sulphuric acid, as described for 110 . The $2 \%$ ethanol in ether eluate from basic alumina on evapoartion gave the described barbiturate ester $(1.14 \mathrm{~g}, 50 \%)$ as an oil, $\mathrm{R}_{\mathrm{F}} 0.62$.

Synthesis of Hexyl 1-methyl-5-(1'-methylbutyl)barbituric acid5-methylene carboxylate (122): The barbiturate carboxylic acid $106 \mathrm{c}(1 \mathrm{~g})$, hexyl alcohol $(3 \mathrm{ml})$, and a few drops of concentrated sulphuric acid were refluxed, as described for 110 . The $2 \%$ ethanol in ether eluate from basic alumina on evaporation gave the required barbiturate ester $(0.47 \mathrm{~g}, 40 \%)$ as an oil, $\mathrm{R}_{\mathrm{F}} 0.63$.

Synthesis of Ethyl 1-methyl-5-pentylbarbituric acid-5-methylene carboxylate(123): 1-Methyl-5-pentylbarbituric acid (50g), ethyl chloroacetate $(30 \mathrm{~g})$, potassium iodide $(0.20 \mathrm{~g})$ and freshly prepared sodium ethoxide solution $(\mathrm{Na}, 5.50 \mathrm{~g})$ were refluxed for 48 hours. The product (123) obtained after column chromatography in basic alumina (56.70gt; 81.0\%), mp. $76-77^{\circ} \mathrm{C}$. Found: C,56.10; H,7.50 and N,9.50\%. $\mathrm{C}_{14} \mathrm{H}_{22} \mathrm{~N}_{2} \mathrm{O}_{5}$ requires: $\mathrm{C}, 56.40 ; \mathrm{H}, 7.40$ and $\mathrm{N}, 9.40 \%$.

1-Methyl-5-pentyl-5-carboxymethyl barbituric acid (120d): Ethyl 1-methyl -5-pentylbarbituric acid (12.0g) was hydrolysed with $(20 \%)$ hydrochloric acid $(30 \mathrm{ml})$ and the reaction on working gave an oil which after crystallization produced colourless crystals of compound (120d), (9g; 83\%), mp. $116-18^{\circ} \mathrm{C}$. Found: C,53.20; H,6.65 and $\mathrm{N}, 10.20 \% . \mathrm{C}_{12} \mathrm{H}_{18} \mathrm{~N}_{2} \mathrm{O}_{5}$ requires: $\mathrm{C}, 53.30 ; \mathrm{H}, 6.70$ and $\mathrm{N}, 10.46 \%$.

Synthesis of Isopropyl 1-methyl-5-pentylbarbituric acid-5methylene carboxylate (124): The barbiturate carboxylic acid 106d $(1.3 \mathrm{~g})$ and isopropyl alcohol were refluxed in the presence of a few drops of concentrated sulphuric acid, as for 107 . The $25 \%$ ethanol in ether eluate from basic alumina on evaporation gave the ester $(1.1 \mathrm{~g}$, $73 \%$ ) as an oil, $\mathrm{R}_{\mathrm{F}} 0.60$.

Synthesis of 2-Bromoethyl 1-methyl-5-pentylbarbituric acid-5methylene carboxylate (125): The barbiturate carboxylic acid 106d $(1.5 \mathrm{~g})$ was refluxed in 2-bromoethanol $(6 \mathrm{ml})$ in the presence of a few drops of concentrated sulphuric acid, as described for 107 . The $2 \%$ ethanol in ether eluate from basic alumina was evaporated to give the barbiturate ester $(1.23 \mathrm{~g}, 59 \%)$ as an oil, $\mathrm{R}_{\mathrm{F}} 0.62$.

Synthesis of p-Acetamidophenyl 1-methyl-5-pentylbarbituric acid-5-methylene carboxylate (126): 1-Methyl-5-pentyl-5carboxymethyl barbituric acid $(1.5 \mathrm{~g})$ was dissolved in thionyl chloride $(6 \mathrm{ml})$ then paracetamol $(1.5 \mathrm{~g})$ was added and the mixture was stirred for $1 \mathrm{~h}$. The deep red residue obtained after evaporation 
of the solvent was triturated with eater and taken up in ether. The extract was washed eith water, decolourised with activated charcoal, and chromatographed on basic alumina. A brown oil of the desired barbiturate ester $(0.63 \mathrm{~g}, 29 \%)$ was obtained from the $2 \%$ ethanol in ether fraction from basic alumina, $\mathrm{R}_{\mathrm{F}} 0.61$.

Synthesis of Phenyl 1-methyl-5-pentylbarbituric acid-5-methylene carboxylate (127): The barbiturate carboxylic acid 106d (2g), thionyl chloride $(6 \mathrm{ml})$, and phenol $(2 \mathrm{~g})$ were stirred, as described for 126 . The $2 \%$ ethanol in ether eluate from basic alumina was evaporate to give an oil of the barbiturate ester $(0.5 \mathrm{~g}, 19 \%), \mathrm{R}_{\mathrm{F}} 0.59$.

1-Methyl-5-hexylbarbituric acid: Methyl urea (31.6g) and diethyl hexylmalonate $(100 \mathrm{~g})$ were refluxed in freshly prepared sodium ethoxide solution ( $\mathrm{Na}, 9.5 \mathrm{~g})$, as described for 1-methyl-5-(1methylbutyl) barbituric acid. The resulting oil was chromatographed on neutral alumina and the ether eluate was concentrated to give the barbituric acid (95g, 88\%), m.p. 66-68 ${ }^{\circ} \mathrm{C}, \mathrm{R}_{\mathrm{F}} 0.28$.

Synthesis of Ethyl 1-methyl-5-hexylbarbituric acid-5-methylene carboxylate (128): An ethanolic solution of 1-methyl-5hexylbarbituric acid $(30 \mathrm{~g})$ was run in to a freshly prepared sodium ethoxide solution $(\mathrm{Na}, 3 \mathrm{~g})$ containing ethyl chloroacetate $(16 \mathrm{~g})$ and potassium iodide $(0.2 \mathrm{~g})$, before refluxing for $48 \mathrm{~h}$, as described for 120a. The resulting oil was chromatographed on basic alumina and the ether eluate was evaporated then taken up in a minimal volume of petroleum ether $\left(30-40^{\circ} \mathrm{C}\right)$ and left at room temperature for 4 days to give colourless crystals of ethyl 1-methyle-5-hexylbarbituric acid5-methylene carboxylate $\left(37 \mathrm{~g}, 89 \%\right.$ ), m.p. $53-54^{\circ} \mathrm{C}$ (Found: C, 58.0; $\mathrm{H}, 7.95 ; \mathrm{N}, 9.0 . \mathrm{C}_{15} \mathrm{H}_{24} \mathrm{~N}_{2} \mathrm{O}_{5}$ requires $\mathrm{C}, 57.7 ; \mathrm{H}, 7.7$ and $\mathrm{N}, 9.0 \%$ ), $\mathrm{R}_{\mathrm{F}} 0.50$.

1-Methyl-5-hexyl-5-carboxymethyl barbituric acid (106e): Ethyl 1-methyl-5-hexylbarbituric acid-5-methylene carboxylate (10g) was treated with $20 \%$ hydrochloric acid $(25 \mathrm{ml})$, as described for $106 \mathrm{c}$. The resulting product was recrystallised from ether-petroleum ether (40$\left.60^{\circ} \mathrm{C}\right)$ to give 1-methyl-5-hexyl-5-carboxymethyl barbituric acid $(8 \mathrm{~g}$, $88 \%$ ), m.p. $114-15^{\circ} \mathrm{C}$ (Found: C, 54.7; H, 7.0; N, 10.0; $\mathrm{C}_{13} \mathrm{H}_{20} \mathrm{~N}_{2} \mathrm{O}_{5}$ requires $\mathrm{C}, 54.9 ; \mathrm{H}, 7.0$; and $\mathrm{N}, 9.9 \%$ ).

Synthesis of Propyl 1-methyl-5-hexylbarbituric acid-5-methylene carboxylate (129): The barbiturate carboxylic acid 106e (2g) was refluxed in propyl alcohol in the presence of a few drops of concentrated sulphuric acid, as for 107 . The $2 \%$ ethanol in ether eluate from basic alumina was evaporated to give the desired barbiturate ester $(1.6 \mathrm{~g}, 69.5 \%)$ as an oil, $\mathrm{R}_{\mathrm{F}} 0.54$.

Synthesis of Isobutyl 1-methyl-5-hexylbarbituric acid-5methylene carboxylate (130): The barbiturate carboxylic acid 106e $(2 \mathrm{~g})$ was refluxed with a few drops of concentrated sulphuric acid in isobutyl alcohol $(6 \mathrm{ml})$, as described for 107 . The $2 \%$ ethanol in ether fraction from basic alumina was evaporated and then crystallised from ether-petroleum ether $\left(40-60^{\circ} \mathrm{C}\right)$ to give needles of the required barbiturate ester $(1.62 \mathrm{~g}, 67.5 \%)$, m.p. $46-48^{\circ} \mathrm{C}, \mathrm{R}_{\mathrm{F}} 0.56$.

Synthesis of Trichloroethyl 1-methyl-5-hexylbarbituric acid-5methylene carboxylate (131): The barbiturate carboxylic acid 106e $(2 \mathrm{~g})$ was refluxed in trichloroethanol $(4 \mathrm{ml})$ in the presence of a few drops of concentrated sulphuric acid, as for 107 . The $2 \%$ ethanol in ether eluate from basic alumina was evaporated to give the barbiturate ester $(1.13 \mathrm{~g}, 38.5 \%)$, as an oil.

1-Methyl-5-cyclohexylbarbituric acid: Diethyl cyclohexylmalonate $(127 \mathrm{~g})$ and methyl urea $(39 \mathrm{~g})$ were dissolved in sodium methoxide solution (108g) ans refluxed, as for 1-methyl-5-(1'-methylbutyl) barbituric acid. The crystals were collected, washed with water, and dried at $100^{\circ} \mathrm{C}$ and the mother liquor was then extracted with ether, washed, dried $\left(\mathrm{Na}_{2} \mathrm{SO}_{4}\right)$ and evaporated. The oil thus obtained deposited crystals from ehter-petroleum ether $\left(40-60^{\circ} \mathrm{C}\right)$ which were combined with the previous crystals. Recrystallisation from etherpetroleum ether $\left(40-60^{\circ} \mathrm{C}\right)$ gave colourless crystals of the barbituric acid $(70 \mathrm{~g}, 63 \%)$, m.p. $156-57^{\circ} \mathrm{C}$.

Ethyl 1-methyl-5-cyclohexylbarbituric acid-5-methylene carboxylate: 1-methyl-5-cyclohexylbarbituric acid (12g), ethyl chloroacetate $(7.2 \mathrm{~g})$, and potassium iodide $(0.1 \mathrm{~g})$ were refluxed in freshly prepared sodium ethoxide solution $(\mathrm{Na}, 1.5 \mathrm{~g})$, as described for 120a. The ether extract was concentrated and chromatographed on basic alumina and the $2 \%$ ethanol in ether eluate was evaporated and then crystallised from ether petroleum-ether $\left(40-60^{\circ} \mathrm{C}\right)$ to give the desired barbiturate ester $(7 \mathrm{~g}, 42 \%)$, m.p. $135-36^{\circ} \mathrm{C}$.

1-Methyl-5-phenylbarbituric acid: Methyl urea (34g) and diethyl phenylmalonate $(100 \mathrm{~g})$ were refluxed in freshly prepared sodium ethoxide solution $(\mathrm{Na}, 10.3 \mathrm{~g})$, as for 1-methyl-5-(1'-methylbutyl) barbituric acid. The crystals were washed with water and dried in an oven at $100^{\circ} \mathrm{C}$. This was then recrystallised from aqueous ethanol to gibe needles of phenylbarbituric acid $(80 \mathrm{~g}, 86.5 \%)$, m.p. $253-54^{\circ} \mathrm{C}$ (Found: $\mathrm{C}, 60.1 ; \mathrm{H}, 4.9 ; \mathrm{N}, 12.6 . \mathrm{C}_{11} \mathrm{H}_{10} \mathrm{~N}_{2} \mathrm{O}_{3}$ requires $\mathrm{C}, 60.55 ; \mathrm{H}, 4.6$ and $\mathrm{N}, 12.8 \%$ ).

Ethyl 1-methyl-5-phenylbarbituric acid-5-methylene carboxylate: 1-Methyl-5-phenylbarbituric acid (10g), ethyl chloroacetate (6.1g), and potassium iodide $(0.2 \mathrm{~g})$ were refluxed in freshly prepared sodium ethoxide solution $(\mathrm{Na}, 1.06 \mathrm{~g})$, as described for 120a. The resulting oil was chromatographed on neutral alumina and the ether eluate was evaporated and then crystallised from ether-petroleum ether (40$60^{\circ} \mathrm{C}$ ) to give fine needles of ethyl 1-methyl-5-phenylbarbituric acid5 -methylene carboxylate $(6.6 \mathrm{~g}, 47 \%)$, m.p. $110-11^{\circ} \mathrm{C}$ (Found: C, 59.3; $\mathrm{H}, 5.3 ; \mathrm{N}, 8.8 . \mathrm{C}_{15} \mathrm{H}_{16} \mathrm{~N}_{2} \mathrm{O}_{5}$ requires $\mathrm{C}, 59.2 ; \mathrm{H}, 5.3$ and $\mathrm{N}, 9.2 \%$ ).

1-Methyl-5-phenyl-5-carboxymethyl barbituric acid: Ethyl 1-methyl-5-phenylbarbituric acid-5-methylene carboxylate $(10 \mathrm{~g})$ was hydrolysed with $20 \%$ hydrochloric acid $(20 \mathrm{ml})$, as for 1-methyl5-methyl-5-carboxymethyl barbituric acid. The resulting product was washed with water and dried in an oven at $100^{\circ} \mathrm{C}$. This was recrystallised from boiling water to give scales of 1-methyl-5-phenyl5-carboxymethyl barbituric acid $(7.8 \mathrm{~g}, 86 \%)$, m.p. $224-25^{\circ} \mathrm{C}$ (Found: C, 56.7; $\mathrm{H}, 4.5 ; \mathrm{N}, 9.8 . \mathrm{C}_{13} \mathrm{H}_{12} \mathrm{~N}_{2} \mathrm{O}_{5}$ requires $\mathrm{C}, 56.6 ; \mathrm{H}, 4.4$ and $\mathrm{N}$, $10.2 \%)$

1-Methyl-5-(1'-methylhexyl)barbituric acid: Methyl urea $(21.3 \mathrm{~g})$ and diethyl 1 -methylhexylmalonate $(75 \mathrm{~g})$ were refluxed in freshly prepared sodium ethoxide solution $(\mathrm{Na}, 6.7 \mathrm{~g})$, as for 1-methyl-5(1'-methylbutyl)barbituric acid. Solvent was distilled off from the reaction and the residue was dissolved in water, acidified with dilute hydrochloride acid extracted with ether. The extract was washed with water, dried, and solvent evaporated. The oil was then crystallised from ether-petroleum ether $\left(40-60^{\circ} \mathrm{C}\right)$ to give colourless needles of 1-methyl-5-(1'-methylhexyl)barbituric acid (50g, 80\%), m.p. 164-65 $5^{\circ}$ (Found: $\mathrm{N}, 12.1 . \mathrm{C}_{12} \mathrm{H}_{20} \mathrm{~N}_{2} \mathrm{O}_{3}$ requires $\mathrm{N}, 11.7 \%$ ).

Synthesis of Ethyl 1-methyl-5-(1'-methylhexyl)barbituric acid-5methylene carboxylate (132): An ethanolic solution of 1-methyl-5$\left(1^{1}\right.$-methylhexyl)barbituric acid $(12 \mathrm{~g})$ was added to a freshly prepared sodium ethoxide solution $(\mathrm{Na}, 0.85 \mathrm{~g})$ containing ethyl chloroacetate $(5 \mathrm{~g})$ and potassium iodide $(0.2 \mathrm{~g})$ before refluxing for $48 \mathrm{~h}$, as for $120 \mathrm{a}$. 
The resulting oil obtained from the ethereal extract after evaporation was chromatographed on basic alumina and the $2 \%$ ethanol in ether eluate was evaporated and then crystallised from ether-petroleum ether $\left(40-60^{\circ} \mathrm{C}\right)$ to give the desired barbiturate ester $(12 \mathrm{~g}, 73.5 \%)$, m.p. $108-10^{\circ} \mathrm{C}$.

1-Methyl-5-(1'-methylpentyl)barbituric acid: Methyl urea $(25 \mathrm{~g})$ and diethyl 1-methylpentylmalonate $(82 \mathrm{~g})$ were refluxed in sodium methoxide solution (76g), as described for 1-methyl-5-(1-methylbutyl) barbituric acid. The resulting product was crystallised from ether to give the required barbituric acid $(61 \mathrm{~g}, 80 \%)$, m.p. $72-73^{\circ} \mathrm{C}$.

Synthesis of Ethyl 1-methyl-5-(1'-methylpentyl)barbituric acid5-methylene carboxylate (133): 1-methyl-5-(1'-methylpentyl) barbituric acid $(21 \mathrm{~g})$, ethyl chloroacetate $(11.7 \mathrm{~g})$, and potassium iodide $(0.2 \mathrm{~g})$ were refluxed in freshly prepared sodium ethoxide solution $(\mathrm{Na}, 2.2 \mathrm{~g})$, as described for $120 \mathrm{a}$. The product was chromatographed on basic alumina and the $2 \%$ ethanol in ether fraction was evaporated to give the desired ester $(26 \mathrm{~g}, 89.3 \%), \mathrm{R}_{\mathrm{F}} 0.65$.

1-Ethyl-5-(1'-methylbutyl)barbituric acid: Ethyl urea (17.4g) and diethyl 1 -methylbutylmalonate $(50 \mathrm{~g})$ were refluxed in sodium methoxide solution (48g), as described for 1-methyl-5-(1methylbutyl)barbituric acid. The resulting thick oily product obtained from the ethereal extract on evaporation was crystallised from etherpetroleum ether $\left(40-60^{\circ} \mathrm{C}\right)$ to give the desired barbituric acid $(36.3 \mathrm{~g}$, $76 \%), R_{F} 0.67$.

1-Allyl-5-(1'-methylbutyl)barbituric acid: Allyl urea (22g) and diethyl 10 methylbutylmalonate $(50 \mathrm{~g})$ were refluxed in sodium methoxide solution (48g), as described for 1-methyl-5-(1methylbutyl)barbituric acid. The desired barbituric acid obtained as an oil $(42 \mathrm{~g}, 81 \%), \mathrm{R}_{\mathrm{F}} 0.35$.

1-Propyl-5-(1'-methylbutyl)barbituric acid: Propyl urea (22g) and diethyl 1 -methylbutylmalonate $(50 \mathrm{~g})$ were refluxed in sodium methoxide solution (48g), as for 1-methyl-5-(1'-methylbutyl) barbituric acid. The desired barbiturate was obtained as an oil $(42 \mathrm{~g}$, $80 \%), R_{F} 0.38$.

\section{Results and discussion}

As reported in earlier communication, it was considered worthwhile to synthesise NH-barbiturates containing carboxylic acid moiety (106) as on esterification, these would have no bulky groups immediately adjacent to the carbonyl function. Various suitable substituents were introduced and the resulting esters were pharmacologically evaluated. Table 2 lists six barbiturates containing a variety of functions in the ester moiety, selected primarily with a view to assessing the influence of $\log \mathrm{P}$ on potency. The data in Table 2 is considered to be insufficient for revealing correlations between substituent parameters and potency on duration of action. At this stage of the investigations into the actions of barbiturate esters it was considered important that some esters should be screened in other species of animals in order to ensure that the results in mice were not atypical. A further series of barbiturate esters listed in Table 3 enables a comparison to be drawn between 5-(1-methylbutyl) and 5-phenyl barbiturates. When compound 107 and 112 are compared for potency with compounds 114 and 115 it appears that the phenyl series is more potent, but the tendency is reversed with other esters in Table $3 \&$ Table 4 . The $\pi$ value of the phenyl group is 1.77 whilst that of the 1-methyl-butyl group is 2.3 . Since only compounds $114(\mathrm{R}=$ butyl; $\pi=2.0)$ and $115(\mathrm{R}=$ pentyl; $\pi=2.5$ ) are more potent in the phenyl series it is possible that the decreased $\pi$ value of the phenyl substituent compensate for the higher $\pi$ values of the ester moieties. Ideally, more results would be required in order to confirm this. Although short acting barbiturate esters were obtained in the carboxylic acid series their potency was still considered to be inadequate for clinical application. Therefore, an attempt was made to incorporate the ester moiety into the more highly lipid soluble $\mathrm{N}$-methyl barbiturates. Compounds $118-133$ (Tables 4-7) were thus prepared and pharmacologically screened. All these compounds, except halogen containing compounds 125 and 131, proved potent. The selection of substituent in Table 4 was determined by the need to assess the influence of $\log \mathrm{P}$ on the potency of the barbiturate esters. The results suggested that the optimal potency had been reached with compounds 118 and 120 where the substituent $\pi$ values were 2.0 and 1.8 respectively. In view of the enhanced potency and very brief duration of anaesthesia with the esters in Table 4 it was decided to test these compounds in rats and rabbits. Tables 5-7 list esters in which the 1-methylbutyl group was replaced by closely related functions. The unbranched pentyl and hexyl functions conferred no advantage. However, the branched chain 1-methylphenyl and 1-methylhexyl barbiturates in table VII are worthy of further investigation since the ethyl esters in these series have moderate potency. Sandberg ${ }^{4}$ investigated the influence of the N-substituent on the activity of $\mathrm{N}$-alkyl-5, 5-diallyl-barbituric acids. His results showed that with increasing $\pi$ values for the $\mathrm{N}$-substituent there was an overall increase in the partition coefficients of his compound, although at the same time their potency was reduced. The synthetic route to the barbiturate esters described in this thesis provided carbethoxy esters which were generally of low potency, presumably because of insufficient lipid solubility. These ethyl esters, therefore, were converted to higher homologues to obtain more active compounds. Since it was felt that the chain lengthening involved in this process might hinder rapid hydrolysis, an alternative means of increasing lipid solubility was sought. The work of Sandberg suggested one way of doing this, hence several $\mathrm{N}$-alkyl esters were synthesised and screened.

\section{Table 5}

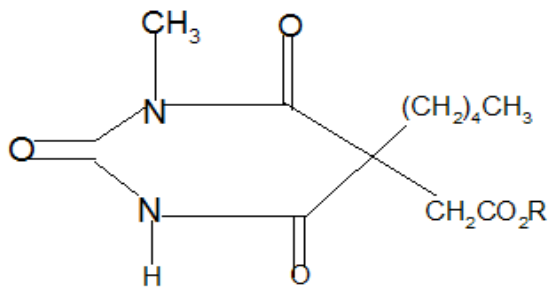




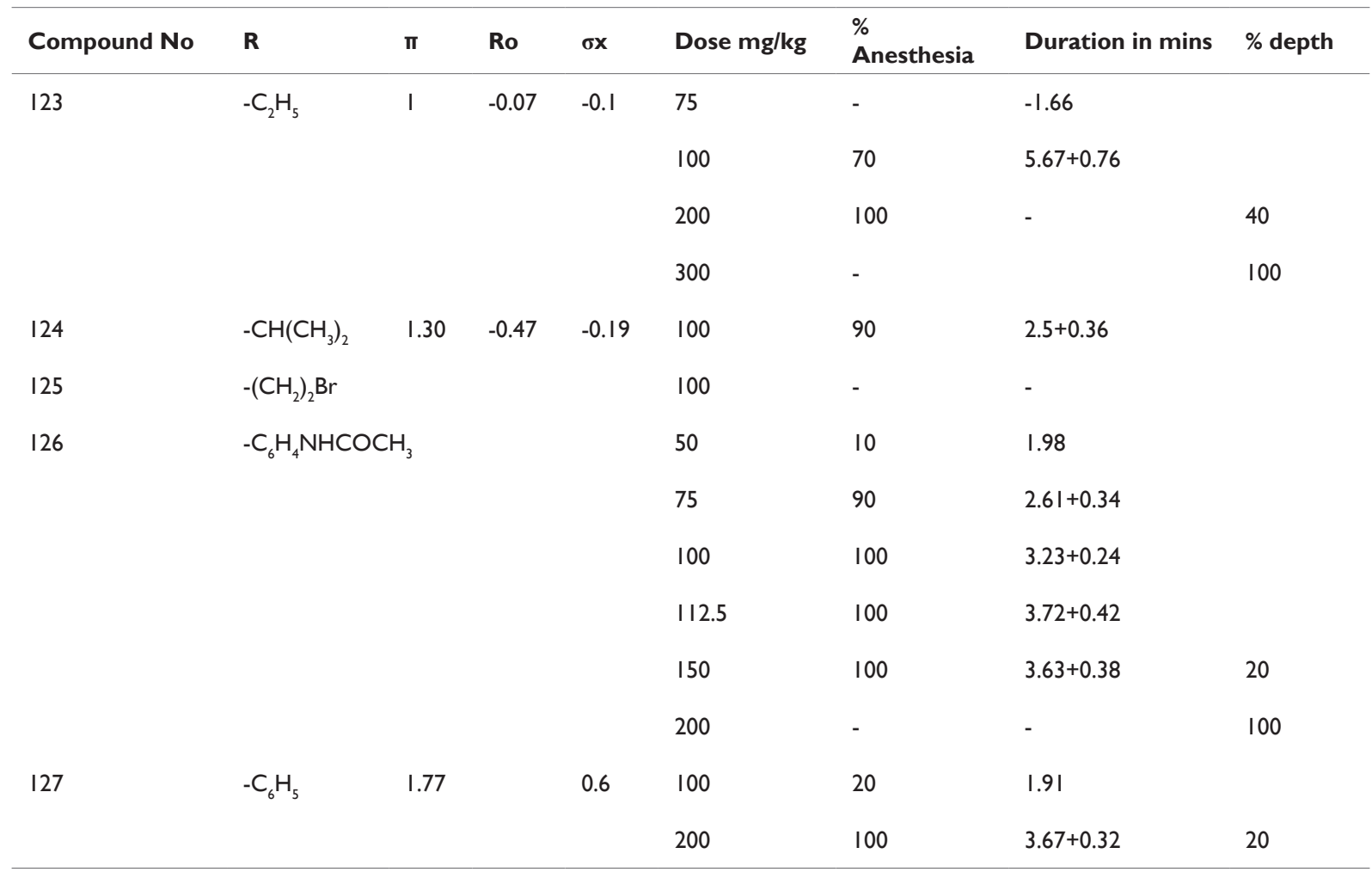

Table 6

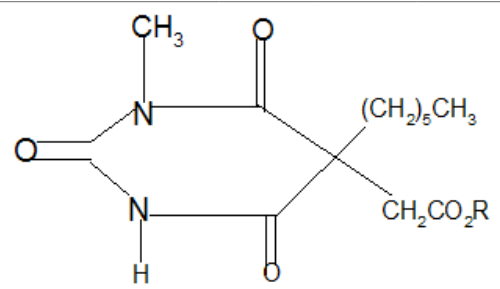

\begin{tabular}{|c|c|c|c|c|c|c|c|c|}
\hline $\begin{array}{l}\text { Compound } \\
\text { No }\end{array}$ & $\mathbf{R}$ & $\pi$ & Ro & $\sigma x$ & Dose mg/kg & $\%$ Anesthesia & Duration in mins & $\%$ depth \\
\hline \multirow[t]{3}{*}{128} & $-\mathrm{C}_{2} \mathrm{H}_{5}$ & 1 & -0.07 & -0.1 & 50 & 20 & 1.13 & \\
\hline & & & & & 100 & 100 & 1.9 & \\
\hline & & & & & 200 & 100 & - & -100 \\
\hline \multirow[t]{5}{*}{129} & $-\left(\mathrm{CH}_{2}\right)_{2} \mathrm{CH}_{3}$ & 1.5 & -0.36 & -0.12 & 30 & - & - & \\
\hline & & & & & 50 & 100 & $4.61+0.29$ & \\
\hline & & & & & 100 & 100 & $7.02+48$ & \\
\hline & & & & & 150 & 100 & $6.3+0.37$ & \\
\hline & & & & & 300 & - & - & 100 \\
\hline \multirow[t]{3}{*}{130} & $-\mathrm{CH}_{2} \mathrm{CH}\left(\mathrm{CH}_{3}\right)_{2}$ & 1.80 & -0.93 & -0.13 & 50 & 70 & $6.48+0.77$ & \\
\hline & & & & & 100 & 100 & $9.46+0.58$ & \\
\hline & & & & & 200 & 100 & $11.7+2.54$ & 80 \\
\hline \multirow[t]{2}{*}{$|3|$} & $-\mathrm{CH}_{2} \mathrm{CCl}_{3}$ & & & & 50 & - & - & \\
\hline & & & & & 100 & - & - & \\
\hline
\end{tabular}

Citation: Huq ME, Sarker A. The synthesis of new barbiturate esters derivatives as intravenous anesthetics: a new dimension of anesthesia route part-IV. Int J Mol Biol Open Access. 2019;4(3):96-104. DOI: 10.15406/ijmboa.2019.04.00104 
Table 7<smiles>[R]C1(CC(=O)OCC)C(=O)NN(C)C(=O)N1C</smiles>

\begin{tabular}{|c|c|c|c|c|c|}
\hline Compound No & $\mathbf{R}$ & Dose & \% Anesthesia & Duration in mins & $\%$ depth \\
\hline 132 & $-\mathrm{CH}\left(\mathrm{CH}_{2}\right)_{4} \mathrm{CH}_{3}$ & 40 & 10 & 6.08 & \\
\hline \multirow{9}{*}{133} & & 50 & 100 & $2.95+0.45$ & \\
\hline & & 150 & 100 & $11.55+0.81$ & 20 \\
\hline & & 175 & 100 & $10.37+1.02$ & 50 \\
\hline & & 200 & 100 & $22.10+1.19$ & 60 \\
\hline & $\left.\right|_{-\mathrm{CH}\left(\mathrm{CH}_{2}\right)_{3} \mathrm{CH}_{3}} ^{\mathrm{CH}_{3}}$ & 50 & 20 & $2.0+0.67$ & \\
\hline & & 75 & 70 & $3.58+0.78$ & \\
\hline & & 100 & 100 & $3.26+0.57$ & \\
\hline & & 150 & 100 & $8.01+0.43$ & 10 \\
\hline & & 200 & 100 & $13.19+0.79$ & 40 \\
\hline
\end{tabular}

\section{Conclusions}

In order to obtain a comprehensive understanding of barbiturate esters as Intravenous Anesthetics, an extensive investigation is necessary of similar or diverse structural compounds.

Note: This is article (part-IV) has been taken from the Doctoral Thesis of the Author, published by Lambert Academic Publications 2017, ISBN: 978-3-330-03143-5.This Thesis was under the Moratorium in the British Patent Office London, UK for 15 years.

\section{Acknowledgments}

The author would like to thank Prof. Stenlake of the Department of Pharmaceutical Chemistry, Strathclyde University, Glasgow, UK for providing the facilities to carry out this work. He is thankful to Mr. Neil Duff for performing Biological tests of the compounds at Aspro- Nicolas Laboratories, Slough, England. The author would like to thank Dr. G.R Proctor and his staffs of the Chemistry Department, Strathclyde University for Chemical and instrumental Analysis. The author acknowledges with appreciation for the financial support as provided under the auspicious of the Technical Cooperation Scheme of the Colombo Plan and administered by the British Council.

\section{Conflicts of interest}

The author declares that there is no conflicts of interest.

\section{References}

1. Mautner HG, Lee CM. J Am Chem Soc. 1965;87:892.

2. Md Ehsanul Huq, Abu Mohammad Azmal Morshed, WE Sneader. Synthesis of New Barbiturate Esters derivatives as Intravenous Anesthetics: A New Dimension of Anesthesia Routes. Archives of Medicine. 2015;7(3):8.

3. Md Ehsanul Huq. Synthesis of New Barbiturate Esters derivatives as Intravenous Anesthetics: A new Dimension of Anesthesia Route: Part- II. International Journal of Pharmaceutical Chemistry. 2018;8(3):18-24.

4. Sandberg F. Acta Physiol Scand. 1951;20:7-26. 